Г. В. Масютина [G. V. Masyutina $]^{1}$

В. Ф. Лубенцов [V. F. Lubentsov $]^{2}$

Е. В. Лубенцова [E. V. Lubentsova $]^{2}$

Е. А. Шахрай [Е. А. Shakhray] ${ }^{2}$

УЛК 681.51

\title{
СИНТЕЗ МНОГОРЕЖИМНОЙ ИНТЕЛЛЕКТУАЛЬНОЙ СИСТЕМЫ УПРАВЛЕНИЯ СЛАБОФОРМАЛИЗУЕМЫМ ПРОЦЕССОМ
}

\section{SYNTHESIS OF A MULTI-MODE INTELLECTUAL SYSTEM OF MANAGEMENT OF A WEAKLY FORMED PROCESS}

${ }^{1}$ Институт сервиса, туризма и дизайна (филиал) ФГАОУ ВО «Северо-Кавказский федеральный университет», г. Пятигорск, e-mail:galinka198@mail.ru

${ }^{1}$ Institute of Service, Tourism and Design (branch) of North-Caucasus Federal State Autonomous Educational Institution of Higher Education Federal University ", Pyatigorsk, e-mail:galinka198@mail.ru

${ }^{2}$ ФГБОУ ВО «Кубанский государственный технологический университет», г. Краснодар, e-mail: f.lubentsov@yandex.ru ${ }^{2}$ FSBEI of HE "Kuban State Technological University",Krasnodar, e-mail: vf.lubentsov@yandex.ru

\begin{abstract}
Аннотация. Отмечены характерные особенности многих промьииленных процессов биотехнических, биотехнологических, пищевых и других производств. К основныи отнесены сложность получения мателатической модели вследствие неполноть знаний кинетических закономерностей, наличия нелинейностей различного вида в математической модели, нестационарность, а также значительная структурная и параметрическая неопределенность, проявляющаяся в проиессе функиионирования. Осущестөлен синтез нейросетевой системы управления проиессом с учетом многорежимности его функционирования в условиях неопределенности. Предложено режииы протекания процесса идентифицировать с помощью характерных изменений скорости изменения концентрации растворенного в среде культивирования автолатически контролируемого углекислого газа в отходящем из аппарата воздухе. На основе проведенного анализа результатов обучения нейронной сети различныли методами установлена уелесообразности приленения алгоритиа ЛевенбергаМарквардта, который обеспечивает больиую точиость и высокуо скорость сходимости вблизи минимума, а, следовапельно, позволяет существенно ускорить проџедуру обучения. Используя алгорити Левенберга-Марквардта, проведено обучение нейросетевых моделей объекта управления, каждая из которых на определенных режимах протекания процесса наиболее приближена к фактическому состоянию объекта. Это позволило реализовать основной принцип работь многорежимных систем управления, заключаюиийся в переключении алгоритмов управления с нейросетевьми моделями при смене режимов прочесса, что позволяет обеспечить задапиье показателей качества системь в каждом из режииов при изменяющихся условиях функиионирования.
\end{abstract}

Ключевые слова: многорежимная система управления, нейросетевая модель, неопределенность модели, объект управления, идентификация режимов, скорость изменения углекислого газа.

Abstract. The characteristic features of many industrial processes of biotechnological, biotechnological, food and other industries are noted. The main ones are the difficulty of obtaining a mathematical model due to the incompleteness of knowledge of kinetic laws, the presence of various types of nonlinearities in the mathematical model, non-stationarity, as well as significant structural and parametric uncertainty that manifests itself in the process of functioning. The synthesis of a neural network process control system was carried out taking into account the multi-mode of its functioning in conditions of uncertainty. It is proposed that the process flow modes be identified using characteristic changes in the rate of change in the concentration of automatically controlled carbon dioxide dissolved in the culture medium in the air leaving the apparatus. Based on the analysis of the results of training the neural network by various methods, the feasibility of applying the Levenberg-Marquardt algorithm, which provides greater accuracy and high convergence rate near the minimum, and, therefore, can significantly accelerate the training procedure, has been established. Using the Levenberg-Marquardt algorithm, we trained neural network models of the control object, each of which, at certain modes of the process, is closest to the actual state of the object. This allowed us to implement the basic principle of multimode control systems, which consists in switching control algorithms with neural network models when changing process modes, which allows us to provide specified system quality indicators in each of the modes under changing operating conditions.

Key words: multimode control system, neural network model, model uncertainty, control object, mode identification, carbon dioxide rate of change.

Introduction. Management of complex poorly formalized biotechnological and technological objects, as well as objects of heat supply systems, occurs, as a rule, under conditions of uncertainty, which is caused by the low reproducibility of the processes occurring in them and the action of uncontrolled disturbances. Such objects are characterized by the absence of a mathematical model due to the incomplete knowledge of kinetic laws, the presence of various types of nonlinear dependencies in the mathematical model, the multiplicity of model variables, as well as the significant uncertainty in the structure and parameters of the model that appears during operation. Such processes include various objects of heat supply systems, chemical, biotechnical and biotechnological, food and other processes of industrial production with their complex and not fully formalized models. Recently, when controlling processes in batch fermentation 
reactors, the principle of differentiating process modes has been introduced: different stages (modes) of the same process are carried out under different conditions in terms of temperature, $\mathrm{pH}$, aeration, etc. Moreover, biologically valuable products are synthesized both in the exponential growth mode (nucleotides, many enzymes, vitamins, which are also called primary metabolites), and in the stationary growth mode (antibiotics, pigments, etc., which are called secondary metabolites), and the optimal conditions of these modes differ . Naturally, multi-mode determines new (additional) requirements for the synthesis of process and object control systems. The functioning of these systems should be carried out in transitional (unsteady) and steady-state modes and ensure the reproduction of a given trajectory of the optimum temperature, stabilization of the optimum temperature, or programmed control of the process temperature depending on the process mode. Currently, biotechnology is increasingly replacing chemical production: it is the production of drugs, vitamins, new fuels, and the solution of environmental problems. Biotechnological processes account for more than $40 \%$ of chemical-pharmaceutical production and this percentage is growing due to the creation of the latest generation of protein-based drugs [1]. In this regard, it seems relevant to synthesize an intelligent control system for poorly formalized processes, taking into account the capabilities of modern software tools and computing power of computers.

The purpose of the study is the implementation of the basic principle of constructing multi-mode control systems by switching control algorithms when changing process modes to provide specified indicators of the quality of the system in each of the modes under changing operating conditions.

Research method. One of the most effective methods for the synthesis of intelligent control systems of poorly formalized processes is a method based on the use of neural network (NS) technology [2,3,4]. However, despite the fact that the duration of the biomass and biosynthesis growth modes in real-time systems can be almost constant, the moments of the onset and end of each of the modes differ significantly. This leads to the need to identify the modes of cultivation and training of the neural network depending on the mode of operation. In this paper, it is proposed to use the parameters of the current state of the process [5] to determine the moments of transition from one mode to another. The rationale for this is as follows. The main modes of almost all biotechnological processes based on the microbiological synthesis of secondary metabolites are two modes: the first mode is the biomass accumulation mode, the second is the biosynthesis mode of the target product. In each of the modes, the ranges of values of the monitored parameters differ significantly, which makes it possible to consider these modes separately. This allows us to significantly simplify the calculations in the synthesis of the optimal control algorithm of the biotechnological process, on the one hand, and to solve the problem of operational switching of control algorithms when changing modes, on the other hand. Thus, the principle of multi-mode controlled biotechnological batch process leads to the need for rapid identification of the moments of the beginning and end of the modes during the operation of the system. We also note that with continuous cultivation there is no change in the regimes of culture development, as with periodic cultivation, and the process constantly proceeds in the regime with exponential growth of the population, therefore, it is not necessary to take into account the differentiation of cultivation regimes by regimes when controlling a continuous process. However, not in all cases a continuous process is preferable to a batch process. For example, at a low specific rate of biomass growth, a periodic process is not inferior to a continuous process in efficiency and is more profitable, since it is easier to implement. In addition, the intensive biosynthesis of many metabolic products occurs with a slow growth of biomass. In batch processes, the concentration of the target product in the culture fluid is usually higher than in continuous, which significantly increases the efficiency of the stages of isolation and purification of the product. All this indicates that periodic processes in the future will be applied and remain the main ones in many domestic productions of vitally important drugs and therefore their management is an urgent task in the context of import substitution.

The use of the flow time of the modes in order to differentiate them, as well as the change of control actions and parameters at predetermined predetermined time intervals, leads to the fact that, due to the low reproducibility of the processes, the optimal flow conditions of one mode are superimposed on others. This leads to a decrease in the effect of the implementation of optimality conditions for each cultivation regimen separately. In this regard, the application of the principle of differentiation of modes necessitates the prompt determination of the time moments of switching modes, which can be done, for example, by means of a characteristic change in automatically controlled environmental parameters [5]. For an example in fig. Figure 1 shows the option when the cell growth rate is not limited by the concentration of the carbon substrate (it is in excess) and, therefore, the specific cell growth rate will be determined mainly by the content of dissolved oxygen $\left(\mathrm{pO}_{2}\right)$ in the medium [1]. However, it should be noted that to measure the composition of the medium, it is necessary to install $\mathrm{pO}_{2}$ sensors, which are located in the device and are sterilized with it with hot steam, as a result of which their characteristics significantly affect the measurement accuracy. Thus, the difficult operating conditions of primary automation measuring instruments, due to the need for their thermal sterilization together with the apparatus on the one hand, and the lack of primary measuring transducers that can withstand steam sterilization, for monitoring and regulating dissolved oxygen, $\mathrm{pH}$, redox potential, on the other parties are a serious obstacle to the control and management of bioprocesses.

A parameter well correlated with $\mathrm{pO}_{2}$ is the carbon dioxide concentration automatically measured in the effluent from the apparatus. If the values of the concentration of oxygen and carbon dioxide in the exhaust air are multiplied by the value of the air flow through the apparatus, then you can get the respiration rate of microorganisms $\left(\mathrm{CO}_{2}\right.$ emissions) and the oxygen consumption rate of the microorganism culture [1]. Shown in fig. The 3 profiles of the "respiratory coefficient" and their practical coincidence for fermentation units of different volumes confirmed the similarity of the 
hydrodynamic situation at certain speeds of rotation of the mixer and air supply to aeration $[1,6]$ and the possibility of using the rate of change in the concentration of carbon dioxide to differentiate cultivation phases.

In fig. Figure 2 shows the operational conditional differentiation of the biomass growth and biosynthesis of the target product using characteristic changes in the sign of the rate of change of automatically controlled carbon dioxide. So, when controlling the process from the mode of adaptation of microorganisms to the mode of exponential growth of microorganisms, the rate of change is $\mathrm{d}\left(\mathrm{CO}_{2}\right) / \mathrm{dt}<0$, and to the mode of slowing the growth of microorganisms $\mathrm{d}\left(\mathrm{CO}_{2}\right) / \mathrm{dt}>0$. From the above it follows that the information content of the $\mathrm{CO}_{2}$ concentration is sufficient in order to use the concentration of $\mathrm{CO}_{2}$ and its rate of change in various modes as inputs of a neural network system to support decision-making on the management of the process as a whole.

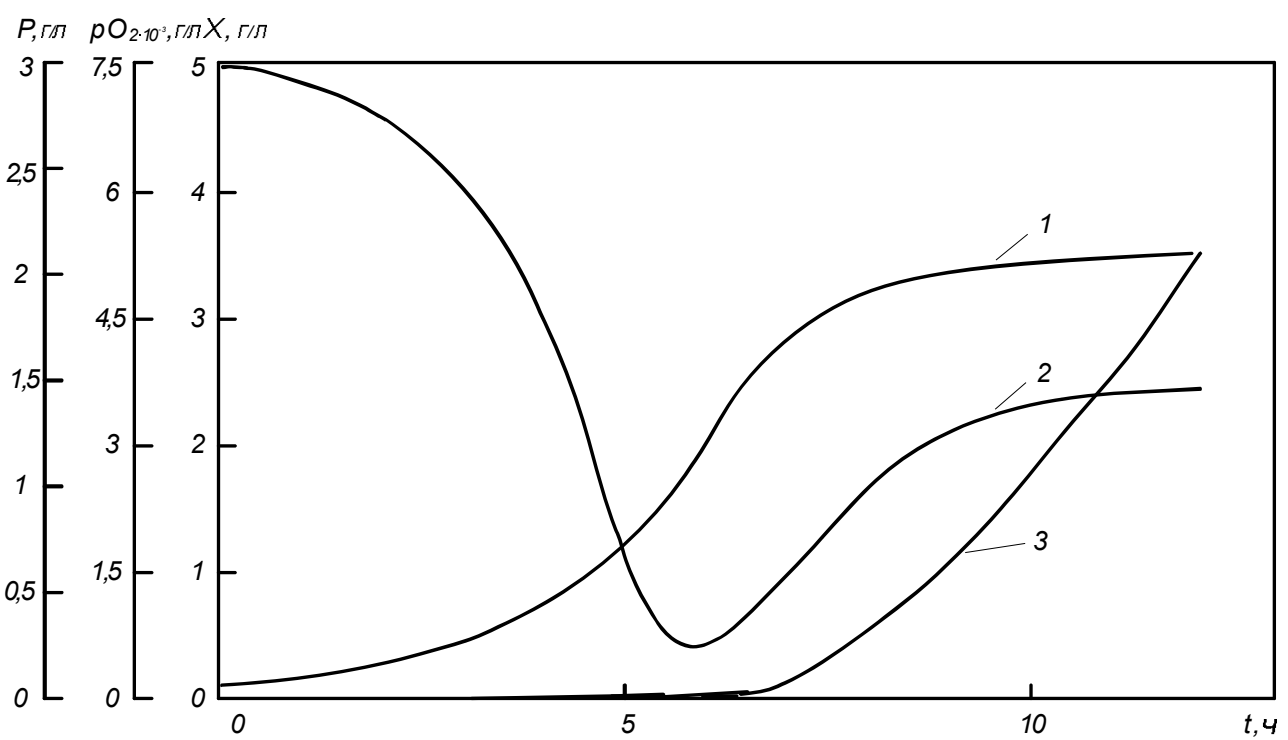

Fig. 1. Schedule of operational conditional differentiation of modes by speed changes in $\mathrm{pO}_{2}$ concentration: 1 - cell growth curve (X); 2 - curve of dissolved oxygen $\left(\mathrm{pO}_{2}\right) ; 3$ - concentration of accumulated protein by cells $(\mathrm{P})$ [1]

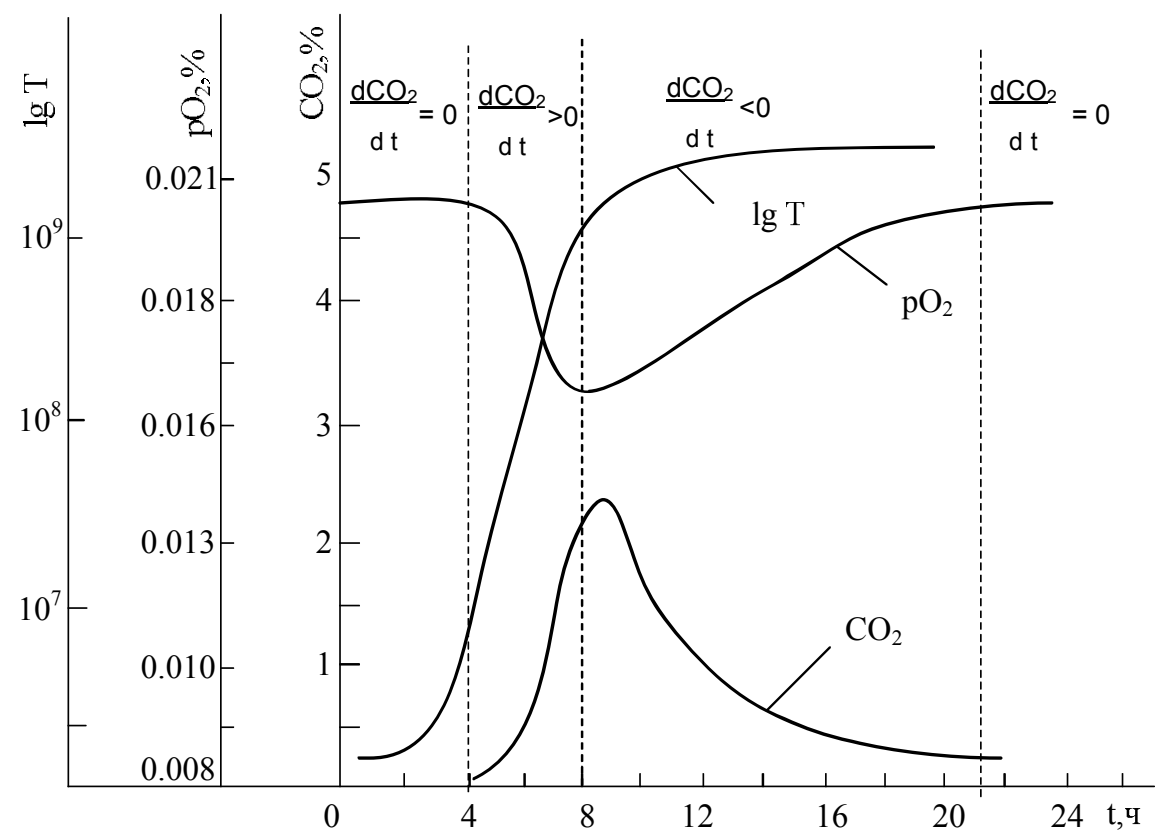

Fig. 2. Schedule operational identification of biomass growth regimes and biosynthesis of the target product by the rate of change of $\mathrm{CO}_{2}$ in the air leaving the apparatus: $\log \mathrm{T}$ is the logarithm of the spore titer; $\mathrm{pO} 2$ is the concentration of dissolved oxygen;

$\mathrm{CO}_{2}$ - concentration of carbon dioxide in the exhaust air; $\mathrm{d}\left(\mathrm{pO}_{2}\right) / \mathrm{dt}$ - rate of change of $\mathrm{pO}_{2}$ 


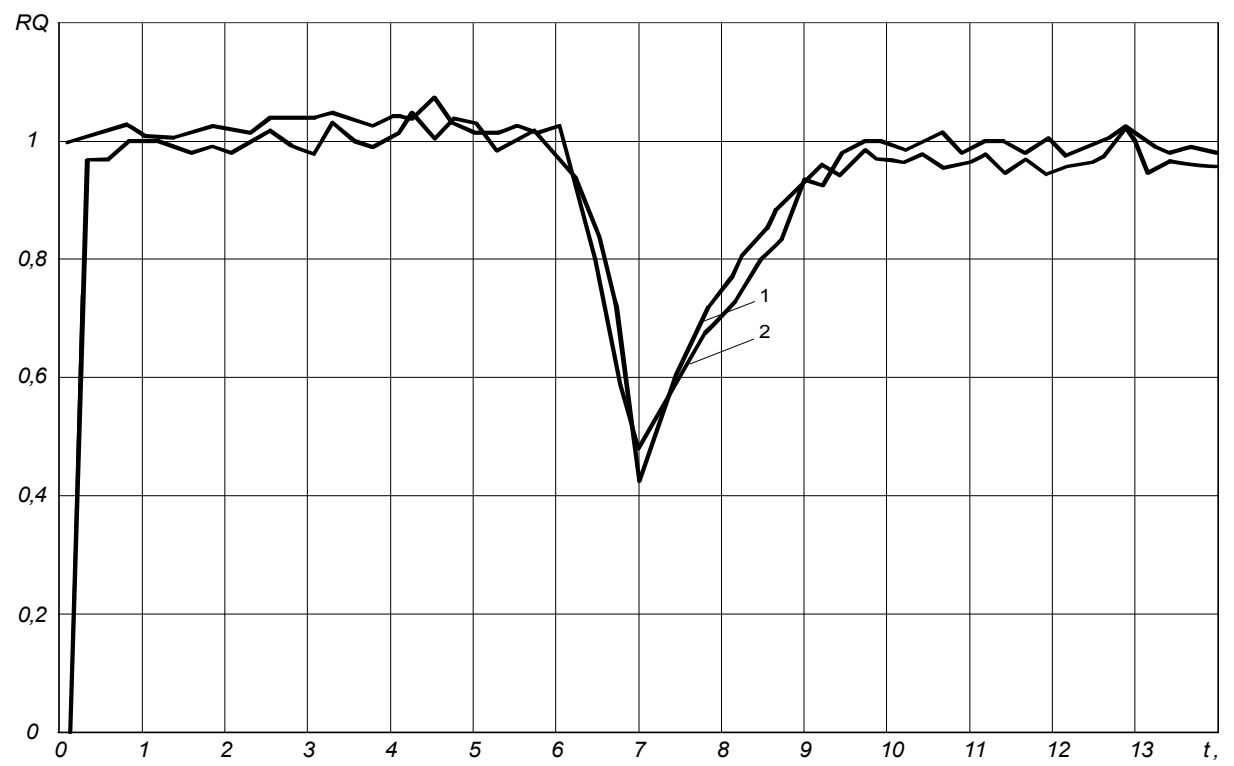

Fig. 3. The profile of the "respiratory coefficient" for units with a volume of 3001 (1) and a volume of 151 (2) [1]

The learning process of the neural network model is carried out as a result of minimizing the objective function some functional $\mathrm{J}$ characterizing the quality of training [8]. The functional is the standard error between the vectors of the desired (target) and real output of the NS:

$$
J=\frac{1}{2} \sum_{q=1}^{Q} \sum_{i=1}^{S}\left(t_{i}^{q}-a_{i}^{q}\right)^{2}
$$

where $\mathrm{Q}$ is the volume of the training sample; $\mathrm{q}$ is the number of the sample; $\mathrm{S}$ is the number of neurons in the output layer; $a_{i}^{q}-$ is the signal vector element at the network output; $t_{i}^{q}-$ is the vector element of the desired (target) signal values at the output of the network for sampling with number q.

To solve the problem in a neural network basis, a multilayer direct distribution neural network was used. The use of one or another learning algorithm allows us to determine the values of customizable parameters (weights and offsets) of the network that provide the minimum value of the error functional.

Research results and discussion. The results of a comparative analysis of the learning algorithms of the neural network model of a dynamic object are shown in table 1 .

Table 1

The results of training a neural network by various methods

\begin{tabular}{|c|c|c|c|c|c|c|}
\hline \multirow{2}{*}{ Name of training method } & \multicolumn{3}{|c|}{ Maximum accuracy e $=10-5$} & \multicolumn{3}{|c|}{ The maximum number of training cycles $\mathrm{N}=200$} \\
\hline & $\begin{array}{c}\text { number of } \\
\text { training cycles }\end{array}$ & training error & training time & $\begin{array}{c}\text { number of } \\
\text { training cycles }\end{array}$ & training error & training time \\
\hline Fletcher-Reeves method & $\begin{array}{c}15 \\
169 \\
\end{array}$ & $\begin{array}{c}1,0 \\
0,01\end{array}$ & $\begin{array}{l}12,16 \\
145,2 \\
\end{array}$ & $\begin{array}{c}10 \\
100 \\
\end{array}$ & $\begin{array}{c}0,14 \\
5,77 \cdot 10^{-4}\end{array}$ & $\begin{array}{c}8,06 \\
237,0 \\
\end{array}$ \\
\hline Polack-Ribeiro method & $\begin{array}{c}14 \\
181 \\
\end{array}$ & $\begin{array}{c}1,0 \\
0,01\end{array}$ & $\begin{array}{l}11,83 \\
155,7 \\
\end{array}$ & $\begin{array}{c}10 \\
200 \\
\end{array}$ & $\begin{array}{c}0,097 \\
4,9 \cdot 10^{4}\end{array}$ & $\begin{array}{l}8,17 \\
3,34 \\
\end{array}$ \\
\hline $\begin{array}{l}\text { Bruden, Fletcher, Goldfarb } \\
\text { and Shanno method }\end{array}$ & $\begin{array}{c}14 \\
54 \\
154 \\
\end{array}$ & $\begin{array}{c}1,0 \\
0,01 \\
10^{-5} \\
\end{array}$ & $\begin{array}{l}10,67 \\
41,43 \\
116,3 \\
\end{array}$ & $\begin{array}{c}10 \\
200 \\
- \\
\end{array}$ & $\begin{array}{c}0,96 \\
0,04 \\
- \\
\end{array}$ & $\begin{array}{c}4,31 \\
82,81 \\
- \\
\end{array}$ \\
\hline $\begin{array}{l}\text { Levenberg-Marquardt } \\
\text { method }\end{array}$ & $\begin{array}{c}4 \\
9 \\
13 \\
\end{array}$ & $\begin{array}{c}1,0 \\
0,01 \\
10^{-5} \\
\end{array}$ & $\begin{array}{c}5,1 \\
10,63 \\
14,27 \\
\end{array}$ & $\begin{array}{c}10 \\
90 \\
- \\
\end{array}$ & $\begin{array}{c}1,2 \cdot 10^{-4} \\
3,95 \cdot 10^{-8} \\
- \\
\end{array}$ & $\begin{array}{c}9,98 \\
112,4 \\
- \\
\end{array}$ \\
\hline
\end{tabular}

The analysis of the results of training the neural network by various methods, taking into account the stopping criteria - maximum accuracy and maximum number of training cycles - indicates the appropriateness of the LevenbergMarquardt algorithm, which provides greater accuracy and high convergence rate near the minimum, and, therefore, can significantly accelerate the training procedure. Using the Levenberg-Marquardt algorithm as a learning algorithm, we trained neural network models of the control object, each of which, at certain modes of the process, is closest to the actual state of the object, and the corresponding neural network controllers that were previously trained based on information about the model parameters object. To train the neural network, the following data were used: the size of the training sample - 8000; input signal values are random in the range [-6; 6]; the maximum learning error is 0.00001 . The initial number of neurons in the hidden layer is previously assumed to be equal to three. The number of cycles (eras), during each of which all elements of the training sequence are successively fed to the input of the NS, and then its out- 
put values and learning quality indicators are calculated, are taken equal to 200. As a function of activation of the hidden network layer, a hyperbolic tangential function is selected, Belonging to the class of sigmoidal [9]. The function of activating the output layer is selected linear over the entire range of changes in the input argument, since the network outputs can take arbitrary values, if sigmoid functions were used in the last output layer of the network, then the output signals of the network would be limited by the range $[-1 ; 1]$, ie when such a layer of signals with large positive and negative values arrives at the input, its output would tend to one of the indicated limits, which is undesirable. The number of neurons in the hidden layer of the neural network of the predictive model was chosen to be 9 . The training of the neural network ended when the learning error of $1.12 \times 10-8$ was achieved, which is an indicator of the successful stage of the identification of a managed object.

A numerical simulation of a neural automatic control system was carried out when the set action was changed at four I-IV intervals with the following object parameters from the uncertainty interval [3]:

I interval: $K_{o \sigma}=0.383\left[{ }^{0} \mathrm{C} / \mathrm{m} 3 / \mathrm{h}\right] ; \tau=2.8 \mathrm{~min} ; \mathrm{T} 1=14.35 \mathrm{~min} ; \mathrm{T} 2=8.55 \mathrm{~min}$;

II interval: $K_{o \sigma}=0.1042\left[{ }^{0} \mathrm{C} / \mathrm{m} 3 / \mathrm{h}\right] ; \tau=4 \mathrm{~min} ; \mathrm{T} 1=27.26 \mathrm{~min} ; \mathrm{T} 2=17.3 \mathrm{~min}$;

III interval: $K_{\mathrm{o \sigma}}=0.1042\left[{ }^{0} \mathrm{C} / \mathrm{m} 3 / \mathrm{h}\right] ; \tau=4 \mathrm{~min} ; \mathrm{T} 1=41.56 \mathrm{~min} ; \mathrm{T} 2=25.01 \mathrm{~min}$;

IV interval: $K_{\text {об }}=0,0766\left[{ }^{0} \mathrm{C} / \mathrm{m} 3 / \mathrm{h}\right] ; \tau=2.2 \mathrm{~min} ; \mathrm{T} 1=28.16 \mathrm{~min} ; \mathrm{T} 2=16.83 \mathrm{~min}$.

Figure 4 shows the transient processes in an automatic control system (ACS) using a multi-mode biotechnological process using neural network models obtained at various operating modes of the control object and the corresponding neural network regulators.

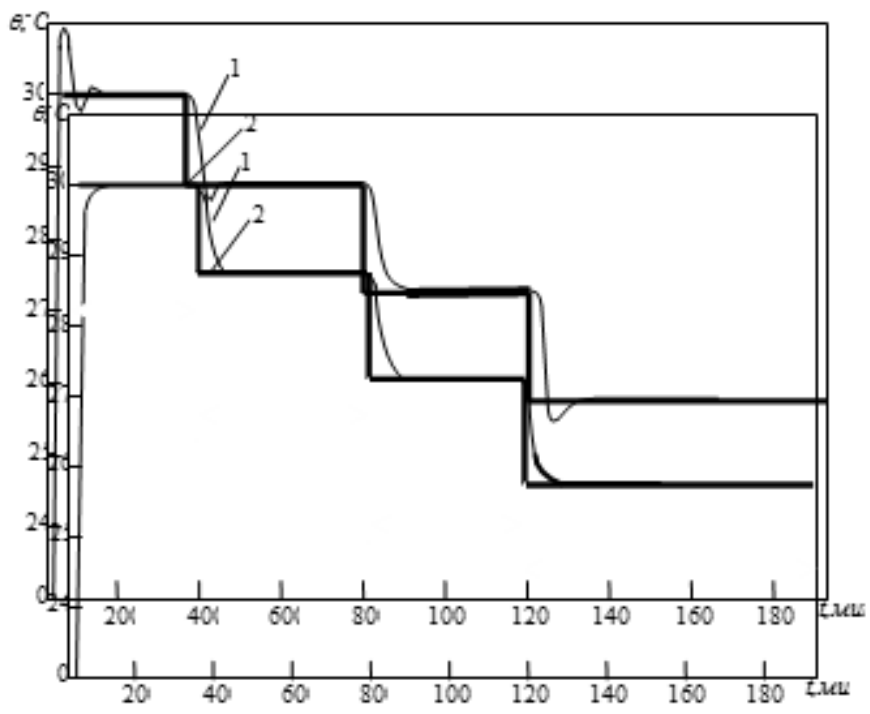

a) b)

Fig. 4. Simulation results of a multi-mode neural network ACS: 1 - transient for a controlled variable; 2 - stepwise setting action; a) ACS operating modes with one neural network model; b) ACS operating modes with four neural network models that are different for each section of the control program

As can be seen from fig. 4, the developed approach to the synthesis of a multi-mode neural network control system for an object allows substantiating a rational structure with switchable neural network models for various modes of a poorly formalized process.

Findings. The use of neural network models in industrial process control systems in combination with the identification of process modes and switchable control algorithms with models for each of the modes gives a positive result and can significantly improve the functioning of a controlled biotechnological system. Performance indicators are high performance in transition mode and increased accuracy of stabilization of operational parameters in steady state.

\section{ЛИТЕРАТУРА}

1. Казеев И.В. Масштабирование процесса микробиологического синтеза рекомбинантных белков (на примере получения рекомбинантного человеческого $\alpha 2$-интерферона) 05.17 .08 Процессы и аппараты химических технологий 03.00 .23 Биотехнология. Автореф. дисс. ... канд. техн. наук.. Казеев И.ля Владимирович; [Место зациты: Рос. хим.-технол. ун-т им. Д.И. Менделеева]. Москва, 2009. 16 с.

2. Терехов В.А., Ефимов Д.В., Тюкин И.Ю. Нейросетевые системы управления. Сер. «Нейрокомпьютеры и их применение». Кн. 8. Под общ. ред. А.И. Галушкина. М.: ИРПЖ. 2002. 480 с.

3. Лубенцов В.Ф. Исследование САУ процессом ферментации с применением технологии нейронных сетей // Приборы и системы. Управление, контроль, диагностика, 2005. № 9. С. 1-4.

4. Рудакова Т.А. Сравнение и выбор нейросетевых моделей на основе метода анализа иерархий [Текст] Т.А. Рудакова, Н.И. Червяков, В.Ф. Лубенцов // Приборы и системы. Управление, контроль, диагностика. 2008 , № 5. С. 1-5. 
5. ІОсупбеков II.P., Бабаянц А.В., Мунгиев А.А., Якубов Э.М. Управление процессами ферментации с применением микро-ЭВМ. Ташкент: Фан, 1987. $200 \mathrm{c}$.

6. Бирюков В. В. Процесс ферментации как объект регулирования температуры / В. В. Бирюков, В. В. Кафаров // Химико-фармацевтический журнал. 1968. № 3. С. 36-39.

7. Бирюков В. В. Растворенный углекислый газ как параметр управления в процессах ферментации / В. В. Бирюков, С. Б. Ицыгин // Химико-фармацевтический журнал. 1976. № 4. С. 122-126.

8. Червяков Н.И. Сравнение алгоритмов обучения нейросетевой модели управления динамическими системами [Текст] / Н.И. Червяков, Т.А. Рудакова, С.Ю. ІҐербина // Нейрокомпьютеры: разработка, применение. М.: Радиотехника, 2008, № 1-2. С. 57-63.

9. Медведев В.С. Нейронные сети. МАТЛАВ 6/ В. С. Медведев, В. Г. Потемкин; Под общ. ред. к. т.н. В. Г. Потемкина. М.: ДИАЛОГ-МИФИ, 2002. 496 с

\section{REFERENCES}

1. Kazeev I.V. Masshtabirovanie protsessa mikrobiologicheskogo sinteza rekombinantnykh belkov (na primere polucheniya rekombinantnogo chelovecheskogo $\alpha 2$-interferona) 05.17.08 Protsessy i apparaty khimicheskikh tekhnologiy 03.00.23 Biotekhnologiya. Avtoref. diss. ... kand. tekhn. nauk.. Kazeev Il'ya Vladimirovich; [Mesto zashchity: Ros. khim.-tekhnol. un-t im. D.I. Mendeleeva]. Moskva, 2009. 16 s.

2. Terekhov V.A., Efimov D.V., Tyukin I.YU. Neyrosetevye sistemy upravleniya. Ser. «Neyrokomp'yutery i ikh primenenie». Kn. 8. Pod obshch. red. A.I. Galushkina. M.: IRPZH. 2002. 480 c.

3. Lubentsov V.F. Issledovanie SAU protsessom fermentatsii s primeneniem tekhnologii neyronnykh setey // Pribory i sistemy. Upravlenie, kontrol', diagnostika, 2005. № 9. C. 1-4.

4. Rudakova T.A. Sravnenie i vybor neyrosetevykh modeley na osnove metoda analiza ierarkhiy [Tekst] / T.A. Rudakova, N.I. Chervyakov, V.F. Lubentsov // Pribory i sistemy. Upravlenie, kontrol', diagnostika. 2008, № 5. C. 1-5.

5. Yusupbekov N.R., Babayants A.V., Mungiev A.A., Yakubov EH.M. Upravlenie protsessami fermentatsii s primeneniem mikro-EHVM. Tashkent: Fan. 1987. 200 s.

6. Biryukov V. V. Protsess fermentatsii kak ob"ekt regulirovaniya temperatury / V. V. Biryukov, V. V. Kafarov // Khimiko-farmatsevticheskiy zhurnal. 1968. № 3. C. 36-39.

7. Biryukov V. V. Rastvorennyy uglekislyy gaz kak parametr upravleniya v protsessakh fermentatsii / V. V. Biryukov, S. B. Itsygin // Khimiko-farmatsevticheskiy zhurnal. 1976. № 4. C. 122-126.

8. Chervyakov N.I. Cravnenie algoritmov obucheniya neyrosetevoy modeli upravleniya dinamicheskimi sistemami [Tekst] / N.I. Chervyakov, T.A. Rudakova, S.YU. Shcherbina // Neyrokomp'yutery: razrabotka, primenenie. - M.: Radiotekhnika, 2008, № 1-2. C. 57-63.

9. Medvedev V.S. Neyronnye seti. MATLAV 6 / V. S. Medvedev, V. G. Potemkin; Pod obshch. red. k.t.n. V. G. Potemkina. - M.: DIALOG-MIFI, 2002. $496 \mathrm{~s}$.

\section{OБ ABTOPAX | ABOUT AUTORS}

Масотиша Галина Владимировна, СКФУ, ИСТиД (филиал) в г. Пятигорске, кандидат технических наук,

доцент кафедры «Физики, электротехники и электроэнергетики», galinka198@mail.ru

Masyutina Galina Vladimirovna, NCFU, ISTiD (branch) in Pyatigorsk, Candidate of Technical Sciences, Associate Professor of the Department of Physics, Electrical Engineering and Power Engineering, e-mail: galinka198@mail.ru

Лубенцов Валерий Федорович, КубГТУ, г. Краснодар, доктор технических наук, профессор кафедры «Автоматизация производственных процессов», e-mail: vf.lubentsov@yandex.ru

Lubentsov Valery Fedorovich, KubGTU, Krasnodar, Doctor of Technical Sciences, Professor of the Department of Automation of Production Processes, e-mail: vf.lubentsov@yandex.ru

Лубенцова Елена Валерьевна, КубГТУ, г. Краснодар, капдидат технических наук, доцент кафедры «Автоматизация производственньх процессов», e-mail: elena-v-1@mail.ru

Lubentsova Elena Valerievna, KubGTU, Krasnodar, Candidate of Technical Sciences, Associate Professor of the Department of Automation of Production Processes,

e-mail: elena-v-1@mail.ru

Шахрай Евгений Александрович, КубГТУ, г. Краснодар, аспирант кафедры «Автоматизация производственных процессов», e-mail: tania_vika@mail.ru Shakhrai Evgeniy Aleksandrovich, KubGTU, Krasnodar, postgraduate student of the Department of Automation of Production Processes, e-mail: tania_vika@mail.ru 